Revista Brasileira de Farmacognosia Brazilian Journal of Pharmacognosy 22(5): 1002-1010, Sep./Oct. 2012

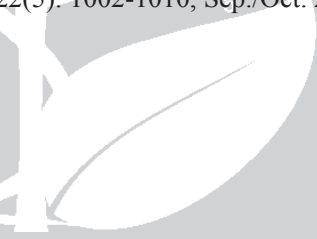

Article

Received 28 Nov 2011

Accepted 6 Feb 2011

Available online 17 Apr 2012

Keywords:

Foeniculum vulgare

FUN-1

fungi

Mentha piperita

Thymus vulgaris

Zingiber officinale

ISSN 0102-695X

http://dx.doi.org/10.1590/S0102-

695X2012005000052

\section{Evaluation of antifungal activity of essential oils against potentially mycotoxigenic Aspergillus flavus and Aspergillus parasiticus}

\author{
Fernanda C. da Silva, ${ }^{1}$ Sara M. Chalfoun,,"2 Virgínia M. de \\ Siqueira, ${ }^{3}$ Deila M. dos S. Botelho, ${ }^{2}$ Nelson Lima, ${ }^{3}$ Luís R. \\ Batista ${ }^{4}$
}

\author{
${ }^{1}$ Departamento de Biologia, Microbiologia Agrícola, Universidade Federal de \\ Lavras, Brazil. \\ ${ }^{2}$ Empresa de Pesquisa Agropecuária de Minas Gerais, Universidade Federal \\ de Lavras, Brazil, \\ ${ }^{3} I B B / C$ entro de Engenharia Biológica, Universidade do Minho, Braga, \\ Portugal, \\ ${ }^{4}$ Departamento de Ciência dos Alimentos, Universidade Federal de Lavras, \\ Brazil.
}

\begin{abstract}
The antifungal activity of essential oils of fennel (Foeniculum vulgare Mill., Apiaceae), ginger (Zingiber officinale Roscoe, Zingiberaceae), mint (Mentha piperita L., Lamiaceae) and thyme (Thymus vulgaris L., Lamiaceae) was evaluated against mycotoxin producers Aspergillus flavus and A. parasiticus. High Resolution Gas Chromatography was applied to analyze chemical constituents of essential oils. The effect of different concentrations of essential oils was determined by solid medium diffusion assay. Mycelial growth and sporulation were determined for each essential oil at the concentrations established by solid medium diffusion assay. At the fifth, seventh and ninth days the mycelial diameter $(\varnothing \mathrm{mm})$ and spore production were also determined. FUN-1 staining was performed to assess cell viability after broth macrodilution assay. Trans-anethole, zingiberene, menthol and thymol are the major component of essential oils of fennel, ginger, mint and thyme, respectively. The effective concentrations for fennel, ginger, mint and thyme were 50, 80, 50 and $50 \%$ (oil/DMSO; v/v), respectively. The four essential oils analysed in this study showed antifungal effect. Additionally, FUN-1 staining showed to be a suitable method to evaluate cell viability of potential mycotoxigenic fungi $A$. flavus and $A$. parasiticus after treatment with essential oils.
\end{abstract}

\section{Introduction}

Aspergillus flavus and A. parasiticus are the predominant species responsible for aflatoxin contamination of crops prior to harvest or during storage (Yu et al., 2004). Many strategies are taken intending to prevent fungal growth and further mycotoxin production and food contamination, including chemical, physical or biological treatments which require sophisticated equipment and expensive chemicals or reagents (Reddy et al., 2010a). The use of natural plant extracts provides an opportunity to avoid chemical preservation, thus the search for new antifungal material natural sources for food preservation has increased (Soliman \& Badea, 2002; Irkin \& Korukluoglu, 2007).

Mycotoxins, i.e. toxic secondary metabolites produced by filamentous fungi, of most concern are produced by species within the genera Aspergillus, Fusarium and Penicillium, which occur in major food crops in the field and continue to contaminate during storage (Reedy et al., 2010b). Aspergillus species are wellknown as active agents in decay processes, as human and animal pathogen and as producer of valuable metabolic products (Raper \& Fennel, 1965). Aspergillus species are also able to cause diseases in economically important crops, such as maize, corn and peanuts, and to produce potent mycotoxins.

Plants known as condiments are traditionally used to enhance taste or aroma of food, and their essential oils (EO) represent a complex mixture of natural substances. EO are known to possess antibacterial and antifungal activity and have been empirically used as antimicrobial agents (Burt, 2004; Bakkali et al., 2008), but the spectrum of activity and mechanisms of action remain unknown for most of them. For EO of plants used as condiments, the antimicrobial activity seems to be associated with phenolic compounds (Simões \& Spitzer, 2000) and the antimicrobial effect is related mainly with changes in the 
permeability and integrity of cell membrane (Lambert et al., 2001; Carson et al., 2006).

FUN-1 is a halogenated asymmetric cyanine compound, virtually no fluorescent in aqueous solution. FUN-1 is permeable to cell membrane and flows through freely into the cell and initially appears in the cytoplasm as a bright diffuse green/yellow stain. In normal fungal cells, FUN-1 is metabolically converted into orange/red cylindrical intravacuolar structures (CIVS). Adenosine triphosphate (ATP) is required for CIVS formation. However, in non-metabolic active cells, the dye remains in the cytoplasm in a diffuse pattern, thus indicating a disorder in the viable state of the cells (Millard et al., 1997).

The aim of this study was to investigate inhibitory concentrations of fennel (Foeniculum vulgare Mill., Apiaceae), ginger (Zingiber officinale Roscoe, Zingiberaceae), mint (Mentha piperita L., Lamiaceae), and thyme (Thymus vulgaris L., Lamiaceae) against mycotoxin producers Aspergillus flavus and A. parasiticus. Mycelial growth and sporulation inhibition effects and broth macrodilution assay for cell viability test using FUN-1 staining were also studied.

\section{Materials and Methods}

\section{Essential oils}

Foeniculum vulgare Mill., Apiaceae, Zingiber officinale Roscoe, Zingiberaceae, Mentha piperita L., Lamiaceae and Thymus vulgaris L., Lamiaceae essential oils were purchase from Ferquima Industry and Trade Ltda, Vargem Grande Paulista-SP, Brazil, and stored in hermetically sealed flasks at $4{ }^{\circ} \mathrm{C}$. Samples of the essential oils as a reference are stored in the Agricultural and Livestock Minas Gerais State Research Institution - EPAMIG, Lavras-MG, Brazil. Analytical gas chromatography was carried out on a Varian CP3380 chromatograph equipped with a flame ionization on Chromatography Laboratory of the Department of Chemistry, Federal University of Minas Gerais, Belo Horizonte/MG, Brazil.We used a column HP-5 (HP) 30 $\mathrm{m} \times 0.25 \mathrm{~mm}$ with a gradient of temperature: $50{ }^{\circ} \mathrm{C}, 3$ min, $3{ }^{\circ} \mathrm{C} /$ min to $170{ }^{\circ} \mathrm{C}$; injector (split $1 / 200$ ) to $200{ }^{\circ} \mathrm{C}$ and detector $200{ }^{\circ} \mathrm{C} . \mathrm{N}_{2}$ as carrier gas $(2 \mathrm{~mL} / \mathrm{min})$ and injection volume $1 \mathrm{~mL}$. Samples were diluted to $0.5 \%$ in chloroform. The identification of peaks was made by calculation of retention index standards for hydrocarbons $\mathrm{C} 10$ to $\mathrm{C} 18$ linear and comparison with literature data (Adams, 2007). The EO were tested pure and dissolved in DMSO (dimethyl sulfoxide) at concentrations of $90 / 10$, 80/20, 70/30; 60/40; 50/50 (v/v; oil/diluent).

Fungal isolates and culture conditions
Aspergillus flavus (CMEcoCentro 00062) and Aspergillus parasiticus (CMEcoCentro 00040) isolated from peanuts and coffee, respectively were used for EO antifungal assay. The fungi were maintained in tubes with potato dextrose agar (PDA: $4 \mathrm{~g} / \mathrm{L}$ potato, dextrose $20 \mathrm{~g} / \mathrm{L}$, agar $15 \mathrm{~g} / \mathrm{L}$ ) at $4{ }^{\circ} \mathrm{C}$.

\section{Antifungal activity of essential oils}

Effect of different concentrations of essential oils

A spore suspension $\left(10^{6}\right.$ spores $\left./ \mathrm{mL}\right)$ was prepared and $120 \mu \mathrm{L}$ of it was spread on dishes with MEA. After absorption, a sterile filter paper disc $(\varnothing 6 \mathrm{~mm})$ was added to the center of the plate and $10 \mu \mathrm{L}$ of different dilutions $(100,90,80,70,60$ and $50 \%)$ of EO were added on it. Filter paper disks impregnated with DMSO only were used as control to confirm no solvent effect on bioactivity. The dishes were incubated for five days at $25{ }^{\circ} \mathrm{C}$. The lowest concentration able to inhibit each fungus (visible inhibition halo around the disk of filter paper) was used in the following test. The tests were performed in triplicate.

\section{Mycelial growth and sporulation assay}

The effect of each EO (i.e., at the EO concentration determined by solid medium diffusion assay) on mycelial growth and sporulation were performed using the in vitro bioanalytical method. For $250 \mathrm{~mL}$ of culture medium Malt Extract Agar (MEA: $20 \mathrm{~g} / \mathrm{L}$ malt extract, $5 \mathrm{~g} / \mathrm{L}$ peptone, $20 \mathrm{~g} / \mathrm{L}$ agar) was added $250 \mu \mathrm{L}$ of each EO. $10 \mathrm{~mL}$ of culture medium containing EO was added to Petri dishes $(\varnothing 90 \mathrm{~mm})$. After solidification, inoculation was made of each fungus at a central point of the dishes. The dishes were incubated at $25{ }^{\circ} \mathrm{C}$ for nine days. At the fifth, seventh and ninth days, it was measured the diameter of the colony $(\varnothing \mathrm{mm})$ and the produce of spore in a Neubauer chamber. The tests were performed in triplicate.

inoculum

Broth macrodilution test using hyphae as

Fungi were tested by the broth macrodilution method for antifungal activity of EO described previously (Espinel-Ingroff et al., 1995). The spore suspension was harvested by flooding each colony with $2 \mathrm{~mL}$ of sterile $0.85 \%$ saline and further diluted to in RPMI 1640 medium to obtain $10^{6}$ spores $/ \mathrm{mL}$. Spore suspension was previously incubated at $35^{\circ} \mathrm{C}$ for $24 \mathrm{~h}$ for the formation of hyphae. A total of $100 \mu \mathrm{L}$ of the fungal suspensions was inoculated into 24-well plates containing $800 \mu \mathrm{L}$ of RPMI medium and $100 \mu \mathrm{L}$ of each EO. Final concentrations, i.e., $50 \%$, $50 \%, 50 \%$ and $80 \%$ for fennel, mint, thyme and ginger, 
respectively were used. EO antifungal activity was evaluated by FUN-1 viability test as further described. RPMI medium added with DMSO alone was used as control to confirm no solvent effect on bioactivity.

\section{FUN-1 viability staining of hyphae}

At each EO concentration tested, fungal hyphae were used for FUN-1 staining (Molecular Probes, The Netherlands) at $48 \mathrm{~h}$ of incubation. For FUN-1 staining, $50 \mu \mathrm{L}$ of hyphae suspension plus $50 \mu \mathrm{L}$ of FUN-1 were added on a Ependorff tube, homogenised, following incubation in the dark at $30^{\circ} \mathrm{C}$ during $30 \mathrm{~min} .20 \mu \mathrm{L}$ of Calcofluor White M2R (CW: 4,4'-bis[4-anilino-6-bis(2ethyl)amino-s-triazin-2-ylamino]-2,2'-disulfonic acid, Molecular Probes, The Netherlands) $(25 \mu \mathrm{M})$ which stains fungal cell walls was also used as counterstain. The excitation/emission wavelength for CW was 346/433 nm and the signal acquired was blue. $20 \mu \mathrm{L}$ of each sample were pipetted on glass slides and observed under an Olympus BX51 epifluorescent microscope using UV light equipped with $40 x / 0.30$ and $10 x / 0.65$ objectives. FUN-1 stains (EX 450-490 nm, EM 520) the dead cells with a diffuse yellow-green fluorescence and the metabolically active cells with red Cylindrical Intra-Vacuolar Structures (CIVS). The images were acquired with a colour camera Zeiss AxioCam HRc using the software CellB ${ }^{\circledR}$. Storage and handling of reagents were performed as recommended by the supplier. Two samples from each well were assayed and examined for staining with FUN-1.

\section{Statistical analysis of experiments}

The data were analyzed by the statistical program Analysis of Variance System for Balanced Data-SISVAR (Ferreira, 2000).

\section{Results}

\section{Essential oils and major constituents}

The major components of EO are listed in Table 1. Trans-anethole (51.5\%), zingiberene (32.7\%), menthol $(55.4 \%)$, and thymol $(54.9 \%)$ were the main components of fennel, ginger, mint, and thyme, respectively.

\section{Effect of different concentrations of essential oils}

Inhibition zones diameters in solid culture of $A$. flavus and $A$. parasiticus are listed in Table 2 . The same concentration of each EO was established for both $A$. flavus and A. parasiticus, i.e. 50\% for fennel, mint, and thyme EO and $80 \%$ for ginger EO (Table 2). For both fungi the $\mathrm{EO}$ of ginger a halo of inhibition was observed at a concentration of $80 \%$.

\section{Mycelial growth and sporulation assay}

The effects of EO on mycelial growth and sporulation of $A$. parasiticus are reported in Table 3 . Throughout the study it was found that each EO showed different effect on mycelial growth and fungal sporulation. All essential oils showed inhibitory effect on mycelial growth of $A$. parasiticus at the seventh and ninth days of analysis (Table 3). For fennel and thyme EO, similar results were observed at the fifth day. Ginger EO showed effect in inhibition of mycelial growth at seventh day (44.66 mm). For sporulation was observed that thyme EO showed inhibitory effect on all analysed days. At the seventh day, the EO of fennel caused a considerable increase in number of spores $\left(4.10 \times 10^{6}\right.$ spores $\left./ \mathrm{mL}\right)$. Same effect was observed for the EO of mint $\left(2.5 \times 10^{6}\right.$ spores/ $\mathrm{mL})$ and ginger $\left(2.18 \times 10^{6} \mathrm{spores} / \mathrm{mL}\right)$ on nine days. The EO of thyme showed the best inhibitory effect on mycelial growth and sporulation of $A$. parasiticus (Table 3 ).

There was no difference in the effect of EO on the A. flavus on the fifth, seventh and ninth days of analysis. The EO of thyme highlighted in the evaluation of mycelial growth and sporulation of $A$. flavus. The EO of fennel presented similar to sporulation control, it is not considered effective in this study.

\section{FUN-1 viability staining}

In this study, positive control of $A$. flavus and $A$. parasitucus (i.e. fungi without the addition of EO) showed green fluorescent hyphae with clearly CIVS (Figures 1A and 2A). Thus, fungi were classified as viable. This same feature was observed with ginger EO, and CIVS were also observed within both $A$. flavus and A. parasiticus hyphae after treatment (Figures 1B and 2B). These result correlate

Table 1. Essential oils and their major constituents used in this work.

\begin{tabular}{|c|c|c|c|c|c|c|c|}
\hline \multicolumn{2}{|c|}{ Fennel } & \multicolumn{2}{|c|}{ Ginger } & \multicolumn{2}{|c|}{ Mint } & \multicolumn{2}{|c|}{ Thyme } \\
\hline trans-anethole & 51.5 & zingibereno & 32.7 & mentol & 55.4 & timol & 54.9 \\
\hline$\delta$-3-careno & 28.7 & sesquifelandreno & 12.9 & mentona & 18.6 & $p$-cimeno & 25.4 \\
\hline \multirow[t]{3}{*}{ fenchona } & 5.7 & $\beta$-bisaboleno & 12.1 & neomental & 5.2 & linalool & 6.0 \\
\hline & & canfeno & 8.2 & & & & 2.8 \\
\hline & & mirceno & 6.9 & & & & \\
\hline
\end{tabular}

Values given are expressed in percentage. 
Table 2. Size of inhibition zone (Ø $\mathrm{mm})$ of mycelial growth of Aspergillus flavus and A. parasiticus at different EO concentrations.

\begin{tabular}{|c|c|c|c|c|c|c|}
\hline \multicolumn{7}{|c|}{ Concentrations (essential oil/DMSO; v/v) } \\
\hline Essential oils & $50: 50$ & $60: 40$ & $70: 30$ & $80: 20$ & $90: 10$ & $100: 0$ \\
\hline \multicolumn{7}{|c|}{ Aspergillus flavus } \\
\hline fennel & $2.33 \mathrm{C} \mathrm{ab}$ & $2.33 \mathrm{C} \mathrm{b}$ & $3.00 \mathrm{C} \mathrm{b}$ & $7.66 \mathrm{~B} \mathrm{a}$ & $5.00 \mathrm{BC} \mathrm{b}$ & $84.00 \mathrm{~A} \mathrm{a}$ \\
\hline ginger & $0.00 \mathrm{~A} \mathrm{~b}$ & $0.00 \mathrm{~A} \mathrm{~b}$ & $0.00 \mathrm{~A} \mathrm{~b}$ & $1.66 \mathrm{~A} \mathrm{~b}$ & $1.00 \mathrm{~A} \mathrm{bc}$ & $2.00 \mathrm{~A} \mathrm{c}$ \\
\hline $\operatorname{mint}$ & 4.66 B a & $2.66 \mathrm{~B} \mathrm{~b}$ & $2.33 \mathrm{~B} \mathrm{~b}$ & $2.00 \mathrm{~B} \mathrm{~b}$ & $3.66 \mathrm{~B} \mathrm{bc}$ & $9.66 \mathrm{~A} \mathrm{~b}$ \\
\hline thyme & $4.66 \mathrm{C} \mathrm{a}$ & $9.33 \mathrm{~B} \mathrm{a}$ & $13.66 \mathrm{~B} \mathrm{a}$ & $11.33 \mathrm{~B} \mathrm{a}$ & $84.00 \mathrm{~A} \mathrm{a}$ & $84.00 \mathrm{~A} \mathrm{a}$ \\
\hline DMSO & $0.00 \mathrm{~A} \mathrm{~b}$ & $0.00 \mathrm{~A} \mathrm{~b}$ & $0.00 \mathrm{~A} \mathrm{~b}$ & $1.00 \mathrm{~A} \mathrm{~b}$ & $0.66 \mathrm{~A} \mathrm{bc}$ & $0.00 \mathrm{~A} \mathrm{c}$ \\
\hline control & $0.00 \mathrm{~A} \mathrm{~b}$ & $0.00 \mathrm{~A} \mathrm{~b}$ & $0.00 \mathrm{~A} \mathrm{~b}$ & $0.00 \mathrm{~A} \mathrm{~b}$ & $0.00 \mathrm{~A} \mathrm{c}$ & $0.00 \mathrm{~A} \mathrm{c}$ \\
\hline \multicolumn{7}{|c|}{ Aspergillus parasiticus } \\
\hline fennel & $4.66 \mathrm{~B} \mathrm{~b}$ & $3.66 \mathrm{~B} \mathrm{~b}$ & $6.66 \mathrm{~B} \mathrm{c}$ & $5.33 \mathrm{~B} \mathrm{~b}$ & $4.66 \mathrm{~B} \mathrm{~b}$ & $84.00 \mathrm{~A} \mathrm{a}$ \\
\hline ginger & $0.00 \mathrm{~A} \mathrm{~b}$ & $0.00 \mathrm{~A} \mathrm{~b}$ & $0.00 \mathrm{~A} \mathrm{~b}$ & $0.66 \mathrm{~A} \mathrm{~b}$ & $0.00 \mathrm{~A} \mathrm{~b}$ & $0.66 \mathrm{~A} \mathrm{~b}$ \\
\hline $\operatorname{mint}$ & $2.33 \mathrm{~B} \mathrm{~b}$ & $2.00 \mathrm{~B} \mathrm{~b}$ & $3.00 \mathrm{AB} b c$ & $2.00 \mathrm{~B} \mathrm{~b}$ & $4.33 \mathrm{AB} \mathrm{b}$ & $9.00 \mathrm{~A} \mathrm{c}$ \\
\hline thyme & $26.33 \mathrm{~B} \mathrm{a}$ & $84.00 \mathrm{~A} \mathrm{a}$ & $84.00 \mathrm{~A} \mathrm{a}$ & $23.33 \mathrm{CB}$ a & $84.00 \mathrm{~A} \mathrm{a}$ & $84.00 \mathrm{~A} \mathrm{a}$ \\
\hline DMSO & $0.00 \mathrm{~A} \mathrm{~b}$ & $0.00 \mathrm{~A} \mathrm{~b}$ & $0.00 \mathrm{~A} \mathrm{~b}$ & $1.00 \mathrm{~A} \mathrm{~b}$ & $0.33 \mathrm{~A} \mathrm{~b}$ & $0.00 \mathrm{~A} \mathrm{~b}$ \\
\hline control & $0.00 \mathrm{~A} \mathrm{~b}$ & $0.00 \mathrm{~A} \mathrm{~b}$ & $0.00 \mathrm{~A} \mathrm{~b}$ & $0.00 \mathrm{~A} \mathrm{~b}$ & $0.00 \mathrm{~A} \mathrm{~b}$ & $0.00 \mathrm{~A} \mathrm{~b}$ \\
\hline
\end{tabular}

*Means followed by the same lowercase letter in the column and uppercase letter in a line, do not differ by Tukey test at $5 \%$ probability.

Table 3. Diameter of colony (Ø $\mathrm{mm})$ and sporulation (106 spores $/ \mathrm{mL})$ of Aspergillus parasiticus at fifth, seventh, and ninth days after inoculation.

\begin{tabular}{|c|c|c|c|c|c|c|}
\hline \multirow{2}{*}{ Treatments } & \multicolumn{3}{|c|}{ Diameter of colony (days) } & \multicolumn{3}{|c|}{ Sporulation (days) } \\
\hline & $5^{\text {th }}$ & $7^{\text {th }}$ & $9^{\text {th }}$ & $5^{\text {th }}$ & $7^{\text {th }}$ & $9^{\text {th }}$ \\
\hline fennel $50 \%$ & $21.00 \mathrm{~A} \mathrm{a}$ & $47.33 \mathrm{~B} \mathrm{~b}$ & $61.33 \mathrm{C} \mathrm{bc}$ & $0.41 \mathrm{~A} \mathrm{ab}$ & $4.10 \mathrm{~B} \mathrm{~b}$ & $6.76 \mathrm{~B} \mathrm{~b}$ \\
\hline ginger $80 \%$ & $51.00 \mathrm{AB} \mathrm{b}$ & $44.66 \mathrm{~A} \mathrm{~b}$ & $62.00 \mathrm{~B} \mathrm{bc}$ & $2.76 \mathrm{~A} \mathrm{~b}$ & $1.66 \mathrm{~A} \mathrm{ab}$ & $2.18 \mathrm{~A} \mathrm{ab}$ \\
\hline $\operatorname{mint} 50 \%$ & $36.66 \mathrm{~A} \mathrm{~b}$ & $77.00 \mathrm{AB} b$ & $51.66 \mathrm{~B} \mathrm{~b}$ & $2.16 \mathrm{~A} \mathrm{~b}$ & $5.01 \mathrm{Ab}$ & $2.50 \mathrm{~A} \mathrm{ab}$ \\
\hline thyme $50 \%$ & $16.00 \mathrm{~A} \mathrm{a}$ & $26.00 \mathrm{AB}$ a & $33.33 \mathrm{~B} \mathrm{a}$ & $0.03 \mathrm{~A} \mathrm{a}$ & $0.06 \mathrm{~A} \mathrm{a}$ & $0.15 \mathrm{~A} \mathrm{a}$ \\
\hline control & $43.33 \mathrm{~A} \mathrm{~b}$ & $69.66 \mathrm{~B} \mathrm{c}$ & $74.00 \mathrm{~B} \mathrm{c}$ & $2.25 \mathrm{~A} \mathrm{~b}$ & $2.50 \mathrm{Ab}$ & $1.46 \mathrm{~A} \mathrm{a}$ \\
\hline
\end{tabular}

*Means followed by the same lowercase letter in the column and uppercase letter in a line, do not differ by Tukey test at $5 \%$ probability.

to results found in growth effect assay in which a high ginger oil concentration $(80 \%)$ did not considerably affect fungal growth. The presence of CIVS after treatment with ginger oil classifies both fungi as viable. On the other hand, only bright diffuse yellow/green cytoplasm was observed after treatment with fennel, mint, and thyme (Figures $1 \mathrm{C}-\mathrm{E}$ and $2 \mathrm{C}-\mathrm{E})$. Thus, in this case fungi were classified as non-viable. These same EO showed inhibition effects in both fungi; this feature was also confirmed by FUN-1 staining results.

\section{Discussion}

Recently, the scientific interest in biological properties of EO has been increased. New researches about biological active secondary compounds present in $\mathrm{EO}$ of plants have been seen as a potential way to control fungal contamination (Burt, 2004; Soliman \& Badea, 2002; Tajkarimi et al., 2010). The results obtained on the chemical characterisation of the fennel, ginger, mint, and thyme EO used in this study is according to the large chemical polymorphism for the majority of EO (Sridhar et al., 2003; Gulfraz et al., 2008; Matan et al., 2009; Razzaghi-Abyaneh et al., 2009).

Thyme EO showed better antifungal effect against Aspergillus flavus and A. parasiticus. This antifungal activity is reported in several studies. Soliman \& Badea (2002) reported that thyme EO $(\leq 500$ $\mathrm{ppm}$ ) completely inhibited the growth of $A$. flavus and $A$. parasiticus. This same effect was observed by Nguefack et al. (2004), that the thyme OE at a concentration of $200 \mathrm{ppm}$ reduced the radial growth of $A$. flavus by $81 \%$. Complete inhibition of conidial germination of $A$. flavus was achieved by $1000 \mathrm{ppm}$. Among various plants tested, thyme EO inhibited growth and aflatoxin production of A. parasiticus (Razzaghi-Abyaneh et al., 2009). The same effect was observed for A. flavus (Kumar et al., 2008). Lis-Balchin \& Deans (1997) reported that strong antimicrobial activity could be correlated with essential oils containing high percentage of monoterpenes, 
Fernanda C. da Silva et al.
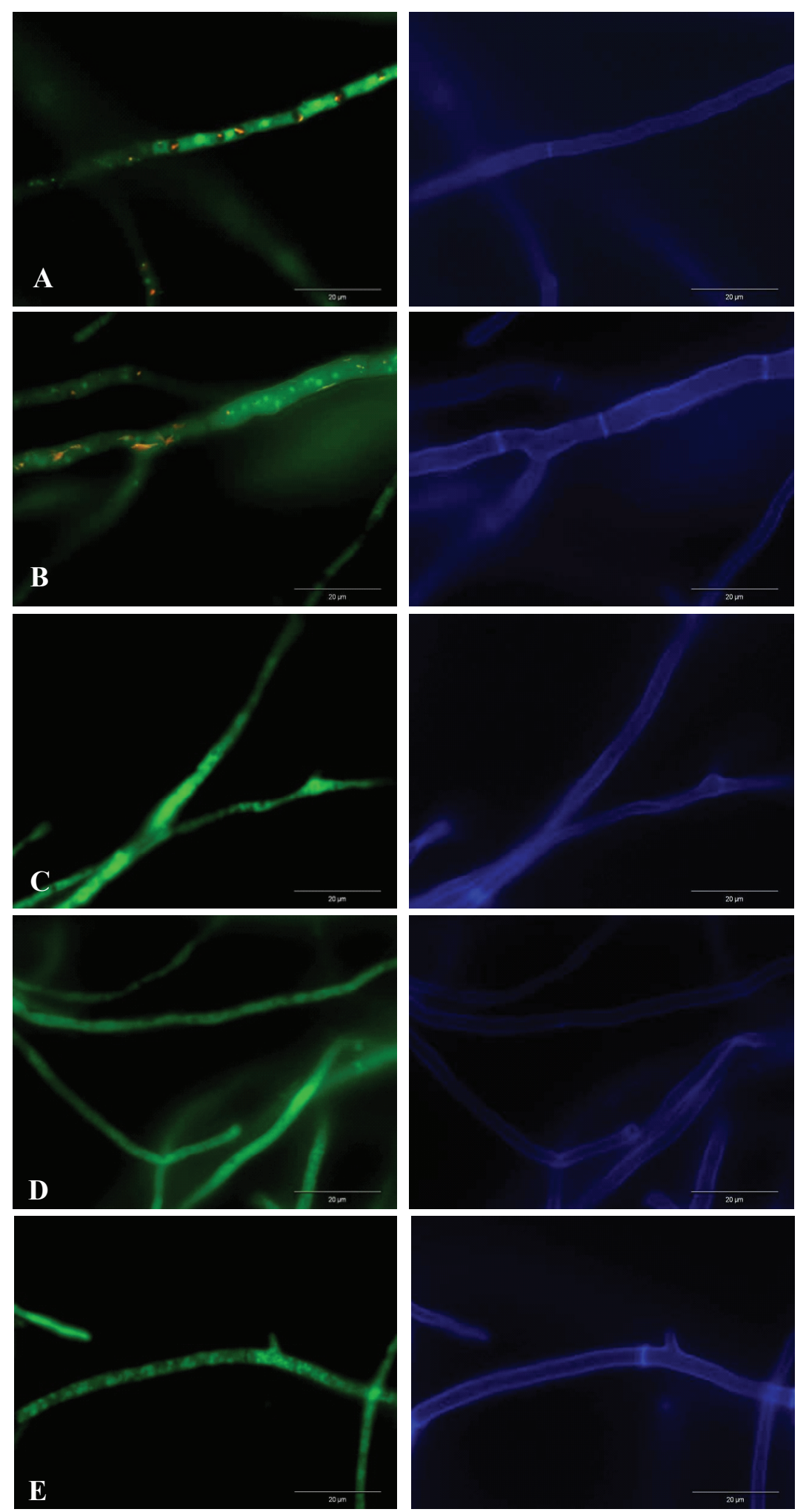

Figure 1. Images of epifluorescence microscope showing Aspergillus flavus after FUN-1 (left column) and CW (right column) staining. Positive control (A) and ginger EO treatment (B) show CIVS. Mint, fennel and thyme EO treatments (C-E) show only yellow/green diffuse hyphae. 

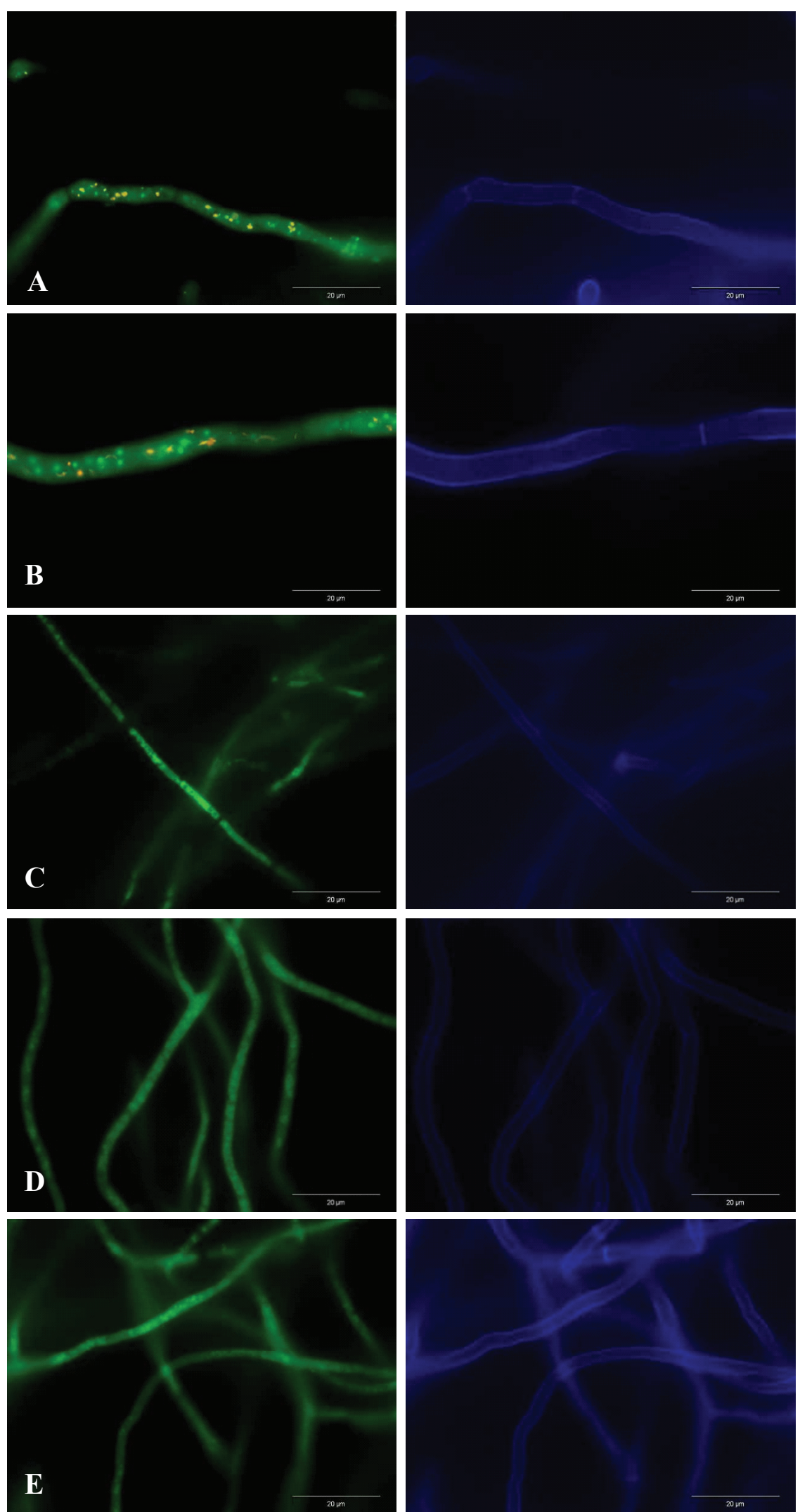

Figure 2. Images of epifluorescence microscope showing Aspergillus parasiticus after FUN-1 (left column) and CW (right column) staining. Positive control (A) and ginger EO treatment (B) show CIVS. Mint, fennel and thyme EO treatment (C-E) show only yellow/green diffuse hyphae. 
eugenol, cinnamic aldehyde, and thymol. It seems possible that phenol components may interfere with cell wall enzymes like chitin synthase/chitinase as well as with the $\alpha$-and $\beta$-glucanases of the fungus (Adams et al., 1996). Thymol, the major constituent of the Thymus vulgaris, in a study by Zambonelli et al. (2004) was correlated with damage to the cell, as increase in the vacuolization of the cytoplasm and an accumulation of lipid droplets, ripples in the plasmalemma and changes in the mitochondria and endoplasmic reticulum of Colletotrichum lindemuthianum and Pythium ultimum. Rasooli et al. (2006) observed severe hyphae collapsing, plasmatic membrane rupture and destruction of mitochondria in Aspergillus niger treated with essential oils of Thymus eriocalyx and T. xporlock.

Antifungal activity of fennel and mint EO is reported in other investigations (Duarte et al., 2005; Özcan et al., 2006; Sokovic \& Van Griensven, 2006; Gulfraz et al., 2008; Freire et al., 2011). The effect antifungal of fennel EO is directly related to its main component transanethole (Patra et al., 2002; Muckenstrum et al., 1997) and the effect of mint EO can be attributed to menthol and 1,8-cineole, which exhibited very good antifungal properties (Griffin et al., 2000).

The ginger EO showed low antifungal activity on the mycelial growth of A. flavus when compared to other EO and ineffective inhibitory effect for the other parameters tested and fungi. No inhibitory effect of fungal growth by this EO was reported in studies by Sridhar et al. (2003) and Thanaboripat et al. (2007). Holley \& Patel (2005) reported that spices, such as ginger, black pepper, red pepper, chili powder, cumin and curry powder showed lower antimicrobial properties.

The differences between the antifungal activity of essential oils studied against $A$. flavus and A. parasiticus and permanence of the inhibitory effect over time are directly related to chemical composition of the EO, the microbial species, the mechanism of action and the method used to analyze the antimicrobial activity of the EO (Bakkali et al., 2008; Pinto et al., 2009; Tajkarimi et al., 2010).

In this study, the method used to evaluate the antifungal activity of EO was solid medium diffusion. Research has shown that this method has limitations. The use of the method is limited to fast-growing microorganisms, aerobic or facultative aerobic (Ostrosky et al., 2008). Another problem noted is the uneven distribution lipophilic components of EO which results in unequal concentrations of $\mathrm{EO}$ in the agar causing the formation of regions with varying antimicrobial activity which can lead to misinterpretations (Lambert et al., 2001; Suhr \& Nielsen, 2003). Ostrosky et al., 2008 also report that the agar diffusion method, the antimicrobial activity of oil can be influenced by the culture medium (agar concentration and origin), $\mathrm{pH}$, oxygen availability, amount of inoculum and incubation conditions. Studies to compare methods of application of EO with antimicrobial activity have been performed (Hammer et al., 2003; Suhr \& Nielsen, 2003).

To corroborate the result of in vitro and verify the feasibility of the method for testing antifungal with EO, cell viability associated FUN-1 staining was performed. This test showed to be a suitable method to evaluate cell viability of potential mycotoxigenic fungi $A$. flavus and $A$. parasiticus after treatment with EO. Studies show that the applicability of fluorescent dyes as a reliable and fast alternative to assess fungal cell viability in environmental and medical fields has been increasingly used (Pina-Vaz et al., 2001; Bowman et al., 2002; Wierzchos et al., 2004). In a study with A. fumigatus, FUN-1 and CW were apply to document patterns of structural changes and its relationship with MIC after following antifungal treatment (Gangwar et al., 2006). CW binds to glucans and chitin in the cell walls and septa of fungi and it has been useful to analyse fungal morphology and as a counterstaining (Agger et al., 1998). Antifungal activity analyses of EO against pathogenic fungi such as A. fumigatus and Candida spp. has been carried out using FUN-1 as well (Pinto et al., 2009). Although the interest in discover new antifungal agents which activity against mycotoxigenic fungi has been increased, a lack of studies in this area still remains and more efforts to establish standardized methods in this area is needed.

Already published results of studies which evaluate antifungal agents indicate that FUN-1 method correlates closely to colony counts method. FUN-1 staining is as a rapid and sensitive method for assaying the viability of fungi and may be applied as an alternative for antifungal tests using EO. In addition, essential oils showed inhibitory effect on fungi tested being, the thyme EO more effective. However, it is necessary to standardize the method for testing antifungal agents with essential oils and more detailed studies on the mechanism of action of these substances in the fungal cell.

\section{Acknowledgements}

The authors are grateful to the colleagues from Laboratory of EPAMIG and Microbiology DEB/UFLA and the Micoteca da Universidade do Minho, Center for Biological Engineering, UMINHO for their support to perform this work. A special aknowledgment is also due to the FAPEMIG and MUM-UMINHO for the financial support of bench work and to CAPES for granting the first author with a PhD scholarship.

\section{References}

Adams S, Kunz B, Weidenbörner M 1996. Mycelial 
deformations of Cladosporium herbarum due to the application of eugenol and carvacrol. J Essent Oil Res 8: 535-540.

Adams RP 2007. Identification of essential oil components by gas chromatography/mass spectrometry. Carol Stream, Illinois: Allured Publishing Corporation.

Agger T, Spohr AB, Carlsen M, Nielsen J 1998. Growth and product formation of Aspergillus oryzae during submerged cultivations: Verification of a morphologically structured model using fluorescent probes. Biotechnol Bioeng 57: 321-329.

Bakkali F, Averbeck S, Averbeck D, Idaomar M 2008. Biological effected of essential oils - A review. Food Chem Toxicol 46: 446-475.

Bowman JC, Hicks PS, Kurtz MB, Rosen H, Schmatz DM, Liberator PA, Douglas CM 2002 The antifungal echinocandin caspofungin acetate kills growing cells of Aspergillus fumigatus in vitro. Antimicrob Agents Ch 46: 3001-3012.

Burt S 2004. Essential oils: their antibacterial properties and potential applications in foods - A review. Int $J$ Food Microbiol 94: 223-253.

Carson CF, Hammer KA, Riley TV 2006. Melaleuca alternifolia (tea tree) oil: A review of antimicrobial and other medicinal properties. Clin Microbiol Rev 19: 50-62.

Duarte MCT, Figueira GM, Sartoratto A, Rehder VLG, Delarmelina C 2005. Anti-Candida activity of Brazilian medicinal plants. J Ethnopharmacol 97: 305-311.

Espinel-Ingroff A, Dawson K, Pfaller M, Anaissie E, Breslin B, Dixon D, Fothergill A, Paetznick V, Peter J, Rinaldi M 1995. Comparative and collaborative evaluation of standardization of antifungal susceptibility testing for filamentous fungi. Antimicrob Agents Ch 39: 314-319.

Freire MM, Jham GN, Dhingra OD, Jardim CM, Barcelos RC, Valente VMM 2011. Composition, antifungal activity and main fungitoxic components of the essential oil of Mentha piperita L. J Food Safety 32: 29-36.

Ferreira, D.F. Análises estatísticas por meio do Sisvar para Windows versão 4.0. In 45a Reunião Anual da Região Brasileira da Sociedade internacional de Biometria. UFSCar, São Carlos, SP, Julho de 2000. p. 255-258. Disponivel em <http://www.dex.ufla.br/ danielff/ softwares.htm>. Acessed 6 Sep 2011.

Gangwar M, Cole R, Ramani R, Sheehan DJ, Chaturvedi V 2006. Application of fluorescent probes to study structural changes in Aspergillus fumigatus exposed to amphotericin B, itraconazole, and voriconazole. Mycopathologia 162: 103-109.

Griffin GS, Markham LJ, Leach ND 2000. An agar dilution method for the determination of the minimum inhibitory concentration of essential oils. J Essent Oil Res 12: 149255.

Gulfraz M, Mehmood S, Minhas N, Jabeen N, Kausar R, Jabeen $\mathrm{K}$, Arshad G 2008. Composition and antimicrobial properties of essential oil of Foeniculum vulgare. Afr $J$
Biotechnol 24: 4364-4368.

Hammer KA, Dry L, Johnson M, Michalak EM, Carson CF, Riley TV 2003. Susceptibility of oral bacteria to Melaleuca alternifolia (tea tree) oil in vitro. Oral Microbiol Immun 18: 389-392.

Holley RA, Patel D 2005. Improvement in shelf-life and safety of perishable foods by plant essential oils and smoke antimicrobials. Food Microbiol 4: 273-292.

Irkin R, Korukluoglu M 2007. Control of Aspergillus niger with garlic, onion and leek extracts. Afr J Biotechnol 6: 384387.

Kumar A, Shukla R, Singh P, Prasad CS, Dubey NK 2008. Assessment of Thymus vulgaris L. essential oil as a safe botanical preservative against post-harvest fungal infestation of food commodities. Innovat Food Sci Emerg 9: 575-580.

Lambert RJ, Skandamis PN, Coote PJ, Nychas GJ 2001. A study of the minimum inhibitory concentration and mode of action of oregano essential oil, thymol and carvacrol. $J$ Appl Microbiol 91: 453-462.

Lis-Balchin M, Deans SG 1997. Bioactivity of selected plant essential oils against Listeria monocytogenes. J Appl Microbiol 82: 759-762.

Matan N, Woraprayote W, Saengkrajang W, Sirisombat N, Matan N 2009. Durability of rubberwood (Hevea brasiliensis) treated with peppermint oil, eucalyptus oil, and their main components. Int Biodeter Biodegr 63: 621-625. DOI: $10.1186 / 1471-2180-10-282$.

Millard PJ, Roth BL, Thi HP, Yue ST, Haugland RP 1997. Development of the FUN-1 family of fluorescent probes for vacuole labeling and viability testing of yeasts. Appl Environ Microb 63: 2897-2905.

Muckenstrum B, Foechterlen D, Reduron JP, Danton P, Hildenbrand M 1997. Phytochemical and chemotaxonomic studies of Foeniculum vulgare. Biochem Syst Ecol 25: 353-358.

Nguefack J, Leth V, Amvam Zollo PH, Mathur SB 2004. Evaluation of five essential oils from aromatic plants of Cameroon for controlling food spoilage and mycotoxin producing fungi. Int J Food Microbiol 94: 329-334.

Ostrosky EA, Mizumoto MK, Lima MEL, Kaneko TM, Nishikawa SO, Freitas BR 2008. Métodos para avaliação da atividade antimicrobiana e determinação da concentração mínima inibitória (CMI) de plantas medicinais. Rev Bras Farmacogn 18: 301-307.

Özcan MM, Chalchat JC, Arslan D, Ateş A, Ünver A 2006. Comparative essential oil composition and antifungal effect of bitter fennel (Foeniculum vulgare subsp. piperitum) fruit oils obtained during different vegetation. J Med Food 4: 552-561.

Pina-Vaz C, Sansonetty F, Rodrigues AG, Costa-de-Oliveira S, Martinez-de-Oliveira J, Fonseca AF 2001. Susceptibility to fluconazole of Candida clinical isolates determined by FUN-1 staining with flow cytometry and epifluorescence microscopy. J Med 
Microbiol 50: 375-382.

Pinto E, Vale-Silva L, Cavaleiro C, Salgueiro L 2009. Antifungal activity of the clove essential oil from Syzygium aromaticum on Candida, Aspergillus and dermatophyte species. J Med Microbiol 58: 1454-1462.

Patra M, Shahi SK, Midgely G, Dikshit A 2002 Utilization of essential oil as natural antifungal against nail infective fungi. Flavour Frag J 17: 91-94.

Raper KB, Fennell DI 1965. The genus Aspergillus. Baltimore: Williams \& Wilkins Company.

Rasooli I, Rezaei MB, Allameh A 2006. Growth inhibition and morphological alterations of Aspergillus niger by essential oils from Thymus eriocalyx and Thymus x-porlock. Food Control 17: 359-364.

Razzaghi-Abyaneh MM, Shams-Ghahfarokhi MB, Rezaee K, Jaimand S, Alinezhad R, Saberi R, Yoshinari T 2009. Chemical composition and antiaflatoxigenic activity of Carum carvi L., Thymus vulgaris and Citrus aurantifolia essential oils. Food Control 20: 1018-1024.

Reddy KRN, Nurdijati SB, Salleh B 2010a. An overview on plant derived products on control of mycotoxigenic fungi and mycotoxins. Asian J Plant Sci 9: 126-133.

Reddy KRN, Salleh B, Saad B, Abbas HK, Abel CA, Shier WT 2010b. An overview of mycotoxin contamination in foods and its implications for human health. Toxin Rev 29: 3-26.

Simões CMO, Spitzer V 2000. Óleos voláteis. In: Simões CMO, Schenkel EP, Gosmann G, Mello JCPD, Mentz LA, Petrovick PR.. Farmacognosia da planta ao medicamento. Porto Alegre: Editora da Universidade Federal do Rio Grande do Sul, p. 387-415.

Sokovic M, Van Griensven LJLD 2006. Antimicrobial activity of essential oils and their components against the three major pathogens of the cultivated button mushroom, Agaricus bisporus. Eur J Plant Pathol 116: 211-224.

Soliman KM, Badea BI 2002. Effect of oil extracted from some medicinal plants on different mycotoxigenic fungi. Food Chem Toxicol 40: 1669-1675.
Sridhar SR, Rajagopal RV, Rajavel R, Masilamani S, Narasimhan S 2003. Antifungal activity of some essential oils. J Agric Food Chem 51: 7596-7599.

Suhr KI, Nielsen PV 2003. Antifungal activity of essential oils evaluated by two different application techniques against rye bread spoilage fungi. J Appl Microbiol 94: 665-674.

Tajkarimi MM, Ibrahim SA, Cliver DO 2010. Antimicrobial herb and spice compounds in food. Food Control 21: 1199-1218.

Thanaboripat D, Suvathi Y, Srilohasin P, Sripakdee S, Patthanawanitchai O, Charoensettasilp S 2007. Inhibitory effect of essential oils on the growth of Aspergillus flavus. KMITL Sci Tech J 7: 1-7.

Wierzchos J, de Los Ríos A, Sancho LG, Ascaso C 2004. Viability of endolithic micro-organisms in rocks from the McMurdo Dry Valleys of Antarctica established by confocal and fluorescence microscopy. J Microsc 1: 5761.

Zambonelli A, D'aulerio AZ, Severi A, Benvenuti S, Maggi L, Bianchi A 2004 Chemical composition and fungicidal activity of commercial essential oils of Thymus vulgaris L. J Essent Oil Res 16: 69-74.

Yu J, Whitelaw CA, Nierman WC, Bhatnagar D, Cleveland TE 2004. Aspergillus flavus expressed sequence tags for identification of genes with putative roles in aflatoxin contamination of crops. FEMS Microbiol Lett 237: 333340 .

\section{*Correspondence}

Sara M. Chalfoun

Empresa de Pesquisa Agropecuária de Minas Gerais, Universidade Federal de Lavras, Caixa Postal 176, 37200-000 Lavras-MG, Brasil.

chaulfon@epamig.ufla.br

Tel.: +3538291190

Fax: +3538216244 